Arkadiusz Barut

opole

DOI: 10.19195/2450-274X.3.4

\title{
Postmodernistyczna struktura i hermeneutyczny autorytet, czyli polityczne implikacje dwóch ponowoczesnych nurtów filozoficznych
}

Abstrakt: Przedmiotem artykułu jest analiza różnic w zakresie filozoficzno-politycznych implikacji postmodernistycznej idei dekonstrukcji oraz hermeneutycznej idei autorytetu.

W niniejszym tekście przyglądam się temu, w jaki sposób krytyka podstawowych kategorii kulturowych przekłada się na stosunek do trwałości porządku społeczno-politycznego. Znana jest krytyka postmodernizmu (a także hermeneutyki) przeprowadzona przez Jurgena Habermasa, zdaniem którego odejście od idei uniwersalności rozumu (choćby w postaci powszechnie ważnych warunków wolnej komunikacji) przekłada się na relatywizm etyczno-polityczny. Moim zdaniem problem z postmodernizmem jest głębszy. Wysnuwam zatem tezę, że postmodernizm, odrzucając obiektywność zarówno ontologiczną, jak i podmiotową, zakłada jednak obiektywność samej dekonstrukcji (w sensie działania politycznego, a nie rozumowania czy procedury naukowej). Tymczasem hermeneutyka Gadamerowska, narażona na zarzut historyzmu i relatywizmu, broni się przed nimi dzięki idei autorytetu.

Słowa kluczowe: postmodernizm, hermeneutyka, autorytet, Derrida, Gadamer

Postmodernist structure, hermeneutic authority, or political implications of two postmodern philosophical currents

Abstract: The subject of the article is the analysis of differences in the philosophical and political implications of the postmodernist idea of deconstruction and the hermeneutic idea of authority.

In this text, I deal with the question of how the critique of basic cultural categories translates into the attitude to the permanence of the socio-political order. There is a known critique of postmodernism (as well as hermeneutics), conducted by Jurgen Habermas, in which the departure from the idea of the universality of reason (even in the form of universally important conditions of free 
communication) translates into ethical and political relativism. In my opinion, the problem with postmodernism is deeper. My thesis is that postmodernism, rejecting ontological and subjective objectivity, assumes, however, the objectivity of deconstruction itself (in the sense of political action, not reasoning or scientific procedure). Meanwhile, Gadamer's hermeneutics, exposed to the charge of historicism and relativism, defend themselves against them thanks to the idea of authority.

Keywords: postmodernism, hermeneutics, authority, Derrida, Gadamer

Przedmiotem artykułu jest analiza różnic w zakresie filozoficzno-politycznych implikacji postmodernistycznej idei dekonstrukcji oraz hermeneutycznej idei autorytetu.

W niniejszym tekście przyglądam się temu, w jaki sposób krytyka podstawowych kategorii kulturowych przekłada się na stosunek do trwałości porządku społeczno-politycznego. Znana jest krytyka postmodernizmu (a także hermeneutyki), przeprowadzona przez Jurgena Habermasa, zdaniem którego odejście od idei uniwersalności rozumu (choćby w postaci powszechnie ważnych warunków wolnej komunikacji) przekłada się na relatywizm etyczno-polityczny. Moim zdaniem problem z postmodernizmem jest głębszy. Wysnuwam zatem tezę, że postmodernizm, odrzucając obiektywność zarówno ontologiczną, jak i podmiotową, zakłada jednak obiektywność samej dekonstrukcji (w sensie działania politycznego, a nie rozumowania czy procedury naukowej). Tymczasem hermeneutyka Gadamerowska, narażona na zarzut historyzmu i relatywizmu, broni się przed nimi dzięki idei autorytetu.

Odwołania do postmodernizmu ograniczam do autorów zaliczanych do francuskiego poststrukturalizmu, uznając, że właśnie w tym nurcie sformułowane zostały hasła najczęściej służące do krytyki kulturowo-politycznej: „dekonstrukcja”, „różnia”, „podmiot nomadyczny”, „łańcuch ekwiwalencji” itp. Za najbardziej interesującą w hermeneutyce uważam hermeneutykę filozoficzną w wersji zaproponowanej przez Hansa-Georga Gadamera; w niej bowiem wyraziło się to, co nurt ten najbardziej różni od postmodernizmu (pomijam więc hermeneutykę „postmodernistyczną") ${ }^{1}$. Hermeneutykę pojmuję przy tym bardziej jako postawę poznawczą niż procedurę naukową ${ }^{2}$.

1 Za Guntherem Scholtzem, odwołującym się do koncepcji Otto Friedricha Bollnowa, przyjmuję rozróżnienie na filozofię hermeneutyczną, zajmującą się problemami istnienia i czasowości, hermeneutykę filozoficzną - teorię rozumienia i interpretowania, wreszcie hermeneutykę techniczną - reguły interpretacji. Zob. G. Scholtz, Czym jest i od kiedy istnieje "filozofia hermeneutyczna", [w:] Studia z filozofii niemieckiej, red. S. Czerniak, J. Rolewski, t. 1. Hermeneutyczna tożsamość filozofii, Toruń 1994, s. 42.

2 Pomijam tutaj okoliczność, iż celem Gadamera było przede wszystkim przedstawienie koncepcji ontologicznej. Istnieją wypowiedzi filozofa, z których zdaje się wynikać, że nie proponował żadnej określonej metodologii, nie wyłączał również stosowania w naukach humanistycznych metod nauk przyrodniczych. W tym sensie ujawnienie interpretacji jako czynnika konstytuującego poznanie miałoby raczej charakter opisu ontologicznego (zob. H.G. Gadamer, Prawda i metoda. Zarys hermeneutyki filozoficznej, przeł. B. Baran, Kraków 1993, s. 24-25), znamienna jest także wypowiedź Gadamera z listu do Emilia Bettiego (zob. A. Bronk, Rozumienie, dzieje, język. Filozoficzna herme- 
O wyborze postmodernizmu i hermeneutyki zadecydowało zarówno historyczne, jak i symboliczne znaczenie tych kierunków. Oba jawią się jako próba odpowiedzi na dwudziestowieczne zakwestionowanie fundamentalnej symboliki polityczno-kulturowej, już nie tylko religijno-tradycyjnej, lecz także postoświeceniowej. Koncepcje te są więc próbą odpowiedzi na pytanie o tożsamość współczesnych społeczeństw europejskich. Szczególnie ważna jest kwestia, jak udzielone odpowiedzi przekładają się na identyfikację źródeł ładu instytucjonalnego - podstawowe zagadnienie interesujące współczesną Europę. Rozważania zawarte w niniejszym tekście mają stanowić przyczynek do dyskusji na temat zarówno kryteriów „wyboru” poszczególnych wątków tradycji europejskiej, jak i różnic pomiędzy tradycją (pojmowaną choćby jako horyzont rozumienia) a konkretnymi postaciami ideologii, którymi uzasadniany jest europejski porządek instytucjonalny.

\section{Idea dekonstrukcji w postmodernizmie}

Założenia epistemologiczne poststrukturalizmu najpełniej wyraża hasło dekonstrukcji rozpowszechnione przez Jacquesa Derridę. Wyszedł on od inspirowanej strukturalizmem koncepcji gramatologii opartej na założeniu, że każde znaczenie odnosi się, w procesie "różni” (différance) ${ }^{3}$, do innego znaczenia, nie ma zaś odniesienia do rzeczywistości zewnętrznej - przedmiotu lub podmiotu. (Ma to stanowić odejście od koncentrowania się na „mowie”, implikującej „metafizykę obecności”, w pełni przejrzystą dla zamiarów podmiotu, zamiast na pozapodmiotowej strukturze - „piśmie”4.) Co więcej, znaczenia te nie wynikają z siebie logicznie, lecz „rozpleniają się”. Filozofowanie musi więc polegać nie na odnajdywaniu obiektywnego sensu czy tworzeniu nowych konstrukcji, a na ujawnianiu przypadkowości już istniejących zapisów - dekonstruowaniu sensu ${ }^{5}$. Idea dekonstrukcji zakłada zatem istnienie znaków, które nie mają jednak koniecznego odniesienia

neutyka H.-G. Gadamera, Lublin 1988, s. 95-96). Niewątpliwie jednak te przesądzenia ontologiczne uzasadniają przyjęcie interpretacji jako postawy badawczej, ze szczególnym uwzględnieniem przekazu tradycji. Należy jednocześnie zauważyć, że również Martin Heidegger uważał, że jego hermeneutyka jako ontologia uzasadnia hermeneutykę jako epistemologię: „[w] tak pojętej hermeneutyce zawarte jest to, co nazwać musimy »hermeneutyką" w sensie pochodnym: metodologia historycznych nauk o duchu" - idem, Sein und Zeit, cyt. za: P. Ricoeur, Jęzk, tekst, interpretacja: wybór pism, przeł. P. Graff, K. Rosner, Warszawa 1989, s. 209.

3 J. Derrida, Różnia, [w:] Drogi współczesnej filozofii, red. M.J. Siemek, przeł. S. Cichowicz et al., Warszawa 1978.

4 Różnia to „przyczynowość konstytutywna wytwórcza i źródłowa, proces rozszczepiania i podziału, którego wytworami lub ukonstytuowanymi skutkami byliby różni lub różnice" - B. Banasiak, Filozofia „końca filozofii”. Dekonstrukcja Jacquesa Derridy, Warszawa 1997, s. 115.

5 B. Banasiak, Jacques Derrida - najgłośniejszy myśliciel XX wieku, http://bb.ph-f.org/teksty/ bb_derrida.pdf (dostęp: 12 września 2015). 
ani do przedmiotów świata zewnętrznego, ani przedmiotów czy stanów świadomości; również ich wzajemne relacje są przypadkowe. Idea ta wyraża przekonanie o nieusuwalnej niepełności i nieadekwatności prób skonceptualizowania świata. Derrida chce usunąć „przemoc” dyskursu, wprowadzając w miejsce centrum jako obecności „nieobecność” (non-lieu) - funkcję mającą umożliwiać nieskończoną liczbę podstawień ${ }^{6}$. Różnia nie jest bytem, ale nie jest też jego zaprzeczeniem. Stanowi „ślad” nieobecności w ,istniejących” elementach. Świat nie ma formy, ale nie jest też nicością, jawi się natomiast jako nieskończona możliwość gry, polegająca na ciągłej dekonstrukcji. Warunkiem objawienia jakiegokolwiek porząaku, choćby ponowoczesnego, jest wprowadzanie chaosu.

Hasło dekonstrukcji wychodzi jednak poza myśl Derridy i jawi się jako charakterystyczne dla całości myśli ponowoczesnej z odrzuceniem przez nią możliwości sformułowania raz na zawsze ustalonych kategorii ontologicznych, poznawczych i etycznych oraz postulatem ciągłego ich przekształcania. Dekonstrukcja konotuje wyjście od uznanego znaczenia w celu ujawnienia nieograniczonej możliwości innych znaczeń - Derrida pisał bowiem, że „trzeba pomyśleć byt jako obecność lub nieobecność, wychodząc do możliwości gry, a nie odwrotnie" ${ }^{7}-\mathrm{w}$ ten sposób ujawniając niemożność jakiegokolwiek ustalonego znaczenia ${ }^{8}$. Idea dekonstrukcji ma więc charakter krytyczny - ma ujawniać historyczną przypadkowość sensów wydających się odzwierciedlać obiektywny stan rzeczy ${ }^{9}$. W myśli politycznej implikuje ona odrzucenie projektu całościowych przekształceń politycznych według z góry ustalonego wzorca (meta-narracji politycznej) na rzecz ciągłych zmian znaczenia poszczególnych idei politycznych, ujawniających niemożność przypisania im ustalonego znaczenia. Obok „postmodernizmu reakcji” uzasadniło to „postmodernizm oporu" asymilowany jeszcze w latach 80 . przez niektórych marksistów dokonujących odrzucenia idei raz na zawsze ustalonej i w każdych warunkach takiej samej „wielkiej narracji” marksistowskiej (Chantal Mouffe, Ernesto Laclau, Jean-François Lyotard $)^{10}$. Również w myśli Derridy w latach 90. nastąpił „zwrot etyczny" przejawiający się w bezpośrednim zastosowaniu konsekwencji jego idei do problematyki etyczno-politycznej (wyrazem tego są dzieła Spectres de Marx, Force de loi oraz Politiques de lamitié; Derrida nawiązał wówczas do myśli Em-

${ }^{6}$ B. Markowska, Gramatologia jako projekt polityczny: dekonstrukcja i kwestia sprawiedliwości, „Idea” 2008, nr 20, s. 8.

7 Cyt. za: ibidem, s. 7.

8 Derrida chce usunąć przemoc mającą tkwić w języku pojętym jako odzwierciedlenie obiektywnych stanów rzeczy, wprowadzając na miejsce centrum jako obecności nieobecność (non-lieu), funkcję umożliwiającą nieskończoną liczbę podstawień. Centrum przekształca się „W system, czyli strukturę zanurzoną w historyczności, żywiole czasu" (ibidem, s. 8), centrum jest więc zarazem wewnątrz struktury jako jej możliwość i na zewnątrz jako jej cel.

9 M. Markowski, Tożsamość i dekonstrukcja, http://p-ntzp.com/dok/11Markowski-p.pdf (dostęp: 19 marca 2014).

10 B. Smart, Postmodernizm, przeł. M. Wasilewski, Poznań 1998, s. 22-23, 39-47. 
manuela Levinasa). Odrzucenie „metafizyki obecności” miało, w zamyśle autora, przełożyć się na etykę uznania Inności ${ }^{11}$, w koncepcji politycznej zaś - mieć swój wyraz w idei la démocratie á venir.

\section{Polityka postmodernizmu - między dekonstrukcją a uznaniem „systemu”}

Prawno-polityczną implikacją dekonstrukcji jest otwarcie normatywne przekonanie o możliwości przekraczania zastanych kategorii polityczno-kulturowych. Opiera się ono na intuicji konieczności zakwestionowania porządku w celu jego zachowania. „Normą” staje się prowizoryczność i niepewność struktury politycznej i prawnej. Nie zostaje ona jednak odrzucona.

W tym miejscu należy przypomnieć postmodernistyczne założenie o pozorności oddzielenia jednostkowości od struktury społecznej. Najbardziej znana jest koncepcja Michela Foucaulta. U autora Archeologii wiedzy ujawnienie podmiotowości jako elementu techniki władzy implikuje odrzucenie tych ideologii emancypacyjnych, które zakładają zniesienie opresji politycznej dzięki przejęciu lub zreformowaniu władzy dyscyplinującej, i wykorzystanie jej dla szczęścia społeczeństwa lub jednostki, jawiących się w oczach reformatora jako w pełni przejrzyste. U Foucaulta opór wobec władzy jest względem niej wewnętrzny - nie tylko jako konieczny skutek jej działań, lecz także jako element ją konstytuujący. Próba uwolnienia się od władzy w imię autentyczności umacnia ją, wprowadza bowiem nowe („autentyczne”), ale równie normalizujące rozumienie podmiotu: „człowiek, o którym tyle nam mówią i do wyzwolenia którego wzywają, jest już, sam w sobie, wynikiem o wiele głębszego ujarzmienia"12. U Gilles’a Deleuze’a zaprzeczenie możliwości postawienia się podmiotu poza strukturą społeczną jawi się właśnie jako czynnik emancypacji. Jest tak dzięki utożsamieniu dynamiki podmiotowości z dynamiką społeczeństwa. Nowożytne pojęcia spontaniczności czy powrotu do natury według Deleuze’a zachowują jeszcze zbyt represyjny charakter, tamujący kreację możliwą tylko w sytuacji zrozumienia braku sprzeczności między nieświadomością a społeczeństwem ${ }^{13}$. By opisać taki podmiot, Deleuze sięga do swojej idei „maszyny”, metafory opisu rzeczywistości (w tym społecznej), wyrażającej spontaniczność działania, kreację i autokonstrukcję ${ }^{14}$.

Nie oznacza to jednak relatywizmu i apolityczności. Przekroczenie uznanych kategorii i symboli prawno-politycznych jawi się jako warunek ciągłego poszu-

11 S. Critchley, The Ethics of Deconstruction. Derrida and Levinas, Oxford-Cambridge 1992.

12 M. Foucault, Nadzorować i karać, przeł. T. Komendant, Warszawa 1993, s. 37.

13 Deleuze krytykuję psychoanalizę Freudowską i Lacanowską za „prywatyzację” problemu nieświadomości poprzez sprowadzenie go do stłumionych relacji między członkami rodziny. Zob. M. Herer, Gilles Deleuze. Struktury - maszyny - kreacje, Kraków 2006, s. 163-172.

14 Ibidem, s. 162-163. 
kiwania sprawiedliwości, co jednak ma miejsce na określonym gruncie społeczno-politycznym. W inspirowanej marksizmem, a zarazem poststrukturalizmem koncepcji Ernesto Laclau przekroczenie jawi się jako warunek istnienia systemu. Laclau, odwołując się do idei Ferdynanda de Saussure’a, stwierdza, że każdy system zakłada granice, które są warunkiem jego istnienia, a zarazem do niego nie należą. Mówiąc o systemie, używa pojęcia, które nie oznacza żadnego z jego elementów. Warunkiem systemu jest więc to, co do systemu nie należy. Systemem jest również możliwość oznaczania. Warunkiem znaczenia jest więc to, co na jego gruncie nie znaczy, co jest niemożliwe: „to, co stanowi warunek możliwości systemu znaczącego - jego granice stanowi również jego warunek niemożliwości - blokadę ciągłego rozszerzania się procesu znaczenia" ${ }^{\prime \prime}$.

Jeśli systematyczność systemu jest bezpośrednim skutkiem wykluczającej granicy, wówczas jedynie owo wykluczenie dostarcza systemowi podstawy [...] system nie może mieć pozytywnej podstawy i w rezultacie nie może oznaczać samego siebie jako pozytywnego elementu znaczonego ${ }^{16}$.

Nie jest to jednak po prostu sprzeczność, absurd, ale tzw. pusta znacząca. „Puste znaczące mogą istnieć w polu znaczenia, ponieważ ośrodkiem struktury każdego systemu znaczenia jest puste miejsce będące wynikiem niemożliwości wytworzenia przedmiotu, który mimo to jest niezbędny dla systematyczności systemu". Jest to więc „niemożliwość pozytywna" ${ }^{\prime 7}$.

Emancypacja może następować gdzieś w przestrzeni między jednostkowością a systemem. U Deleuzéa pragnienie ( $w$ tym natury seksualnej) to nie przedsocjalny instynkt podlegający następnie stłumieniu (sublimacji, ukierunkowaniu itp.) przez normy społeczne. Wręcz przeciwnie, samo pożądanie jawi się, tak jak u Deleuze’a, jako wyraz uspołecznienia, od razu przechodząc w „instytucję”. Nie ma więc sprzeczności między chęcią spełniania pragnień a kształtowaniem więzi społecznej, którą tworzą, według określenia autora Anty-Edypa, właśnie „inwestycje pragnienia” (investissement de désir). Powraca „sprywatyzowana” Foucaultowska idea powszechności władzy. Kluczową kategorią analizy teoretycznopolitycznej są więc te miejsca pola władzy, w których występuje szczególnie dużo inwestycji pragnienia - czyli, jak to określa Deleuze, jej foyer ('ogniska'). Są nimi m.in. niezwykle istotne w zindywidualizowanym społeczeństwie tematy oraz mechanizmy instytucjonalne służące ich przeforsowaniu, w tym ciało i seksualność ${ }^{18}$. W języku

15 E. Laclau, Emancypacje, przeł. L. Koczanowicz et al., Wrocław 2004, s. 68.

16 Ibidem.

17 Ibidem, s. 71. Należy tu przywołać również figurę „Znaczącego - Mistrza” u Slavoja Žižka. Zob. idem, Wzniosty obiekt ideologii, przeł. J. Bator, P. Dybel, Wrocław 2001.

18 G. Lambert, Critical horizons, „Brill Academic Publishers” 4, 2003, z. 2, s. 178-189. Również Foucault w trzecim tomie Historii seksualności, poszukując „pozytywnego" programu etycznego, osłabia napięcie między społeczeństwem a jednostką. „Troska o siebie”, która miała znaleźć pełny wyraz w ideach stoickich i epikurejskich I-II w., to starannie skonceptualizowana postawa prowadząca do „wzmożenia relacji społecznej”; „powstaje dzięki niej nie ćwiczenie w pojedynkę, ale prawdziwa 
teorii ekwiwalencji stanowią one puste znaczące, „naładowane” jednak symboliką polityczną. Według Laclau pustą znaczącą jest przede wszystkim podmiot polityczny - grupa postrzegająca się jako uciskana. Jeśli dzięki logice ekwiwalencji inne grupy uznają ją za symbol oporu przeciw władzy, żądania polityczne, przedstawiane jako jej żądania, nabiorą charakteru ponadpartykularnego, a zarazem, co szczególnie ważne, oderwą się od rzeczywistych interesów czy roszczeń artykułowanych przez członków grupy. Stracą jednak samoistne znaczenie, a tożsamość grupy zostanie pochłonięta przez uniwersalny ruch przekształcania struktury politycznej. Ceną za emancypację polityczną jest zatrata podmiotu z konstytutywną dla jego tożsamości „logiką różnicy”19.

Uznanie istnienia systemu za warunek emancypacji przekłada się też na rozważania o tematyce filozoficzno-prawnej. Warto wrócić do koncepcji Derridy. Dla tego filozofa osoba działająca w sferze politycznej powinna mieć świadomość niemożności wcielenia ideału sprawiedliwości. Stosując ideę „różni” i dekonstrukcji do problematyki prawnej, Derrida zestawia akt twórczej przemocy, związany z każdym aktem interpretacji jako tworzenia nowego sensu, z „potocznym” poglądem na temat prawa jako zjawiska mającego swe źródło w przemocy i potrzebującego jej dla swego zachowania (enforcebility) ${ }^{20}$. Stwierdzając odmienność prawa od sprawiedliwości, ujawnionego przez zabiegi jego dekonstrukcji, Derrida konstatuje zarazem niemożność sformułowania idei sprawiedliwości. Sama sprawiedliwość okazuje się bowiem dekonstrukcją. Wyraża się to w znanym paradoksie Derridiańskim: skoro prawo jest dekonstruowalne, sprawiedliwość zaś jest niedekonstruowalna, to jeśli dekonstrukcja jest sprawiedliwością, to dekonstrukcja ma miejsce pomiędzy niedekonstruowalnością sprawiedliwości i dekonstruowalnością prawa. Jest więc „doświadczeniem niemożliwego" ${ }^{21}$. Koncepcja ta nie jest więc trywialną konstatacją pozaprawnych źródeł prawa pozytywnego. Instytucjonalny charakter prawa jawi się jako niezbędny do jego istnienia - dekonstrukcji może podlegać bowiem wyłącznie istniejący już tekst. Jednocześnie istotowo już w prawie zawarta przemoc może się spotkać z przemocą zawartą w akcie dekonstrukcji. Nie jest zatem właściwe „idealistyczne” oddzielenie prawa od sprawiedliwości $\mathrm{w}$ imię tej ostatniej. Sprawiedliwość domaga się wprowadzenia w życie, a prawo powinno być oparte na sprawiedliwości. Próbą ujawnienia, a zarazem przepracowania tego paradoksu jest właśnie dekonstrukcja ${ }^{22}$.

praktyka społeczna" - idem, Historia seksualności, przeł. B. Banasiak, T. Komendant, K. Matuszewski, t. 3, Warszawa 1995, s. 428, 430.

19 E. Laclau, op. cit., s. 72-78; idem, Populism: what's in a name?, s. 3 n., www.essexs.ac.uk/centres/theostud/documents_and_files/Word/Populism\%20Whats\%20in\%20a\%20name.doc (dostęp: 16 sierpnia 2014).

20 J. Derrida, Force of law, [w:] G. Anidjar, J. Derrida, Acts of Religion, London-New York 2002, s. 233-239.

21 Ibidem, s. 243.

22 Ibidem, s. 248. 
Uświadomienie sobie tej zależności uniemożliwia zarazem jakiekolwiek próby apriorycznego określenia treści sprawiedliwego prawa. Poznanie prawa to jego odnalezienie w konkretnej sytuacji. Nie jest to jednak akt interpretacji hermeneutycznej, nie polega bowiem na połączeniu punktu widzenia interpretatora $\mathrm{z}$ punktem widzenia tradycji. Każdy akt prawny jest poszukiwaniem „niemożliwej” sprawiedliwości. Dlatego też aporia - odnajdywanie (stosowanie, poznawanie) - prawa jest zawsze aktem jego tworzenia ex nihilo, następuje niemożność stwierdzenia, iż prawo jest sprawiedliwe, skoro sprawiedliwość jest niemożliwą do apriorycznego opisania konkretnością, wreszcie bezczasowość prawa jest niemożliwa do uchwycenia partykularną decyzją ${ }^{23}$. Prawo jawi się więc jako $\mathrm{z}$ istoty otwarte na inność, pojętą przez Derridę, jak już wspomniałem, w kategoriach filozofii dialogu ${ }^{24}$. Każda decyzja obarczona jest nieskończoną odpowiedzialnością, pojmowaną nie tyle jako przypisanie jej skutków określonemu podmiotowi, ile jako świadomość konieczności podjęcia próby uchwycenia jej niepowtarzalności, wynikającej z niepowtarzalności Innego ${ }^{25}$. Derridiańska koncepcja prawa po raz kolejny ujawnia swój istotowy związek z twórczą przemocą, która jednak jest możliwa dzięki dekonstrukcji istniejącego już tekstu ${ }^{26}$.

Postmodernizm, dokonując dekonstrukcji dotychczasowych koncepcji podmiotowości politycznej, nie proponuje żadnej nowej jej koncepcji. Po utracie „tożsamości” przez „grupę” nie następuje kreacja czegokolwiek na to miejsce, a „pusta znacząca" jest tylko postulatem, nie zostają wskazane żadne mechanizmy, które prowadziłyby do ukonstytuowania się „pustej znaczącej” jako stabilnej tożsamości. Ostatecznie więc dekonstrukcja jawi się jako „operacja”, która nigdy nie może osiągnąć kresu, ale zawsze musi wyjść nie od „czystej” idei, lecz od jakiegoś układu instytucjonalnego. Nie może wyjść od spontaniczności podmiotu, wychodzi zatem od struktury pozapodmiotowej, która jednak dekonstrukcji nie ogranicza - wręcz przeciwnie, umożliwiając ją, czerpie z niej również swą siłę. „Płynność” struktury, a zarazem jej konieczność (a więc, przynajmniej potencjalnie, jej opresyjność) jawią się jako dwie strony tego samego zjawiska. Postmodernistyczna krytyka władzy może być uznana za jej afirmację.

23 Ibidem, s. 249-253.

24 O paradoksalnym pojmowaniu etyki i prawa u Derridy por. szerzej F. Raffoul, Derrida and the ethics of Im-possible, „Research in Phenomenology” 38, 2008, s. 270-290.

25 Kolejnym kluczowym pojęciem teoretyczno-prawnym, obok enforcebility, jest dla Derridy address. Zob. idem, Force of law, s. 244.

26 Podobnie sprawę ujmuje Deleuze. Również na gruncie jego koncepcji, jeśli źródłem więzi społecznej jest pożądanie, więź społeczna i kontekst instytucjonalny muszą mieć charakter dynamiczny - ich statyczność byłaby autodestrukcyjna. To samo należy odnieść do prawa pozytywnego. Jego sprecyzowanie i formalizacja, pojmowanie go raczej jako zakaz niż czynnik społecznej inwencji, przeprowadzanie rozumowań prawniczych in abstracto zapoznaje jego istotę. Tę zaś winna uchwycić dynamicznie pojmowana, kreatywna, wypracowująca swój pogląd na gruncie konkretnej sytuacji ,jurysprudencja” jawiąca się nie jako metoda zachowania status quo, lecz czynnik społecznej zmiany. Zob. A. Lefebvre, The Image of Law: Spinoza, Bergson, Deleuze, Stanford 2008, s. 56-58. 


\section{Idea tradycji i autorytetu w hermeneutyce}

$\mathrm{W}$ drugiej połowie XX w. szeroko rozumiane podejście hermeneutyczne stało się popularną postawą badawczą $\mathrm{w}$ humanistyce i naukach społecznych. Jego znaczenie wynika $\mathrm{z}$ chęci odejścia od prób stosowania $\mathrm{w}$ tych naukach paradygmatu nauk przyrodniczych (czego wyrazem była filozofia analityczna, strukturalizm, a obecnie jest nim np. neuropsychologia). Hermeneutyka stanowi zarazem, w przeciwieństwie do kierunków postmodernistycznych, próbę zachowania na gruncie humanistyki ponadjednostkowych i w tym sensie obiektywnych kryteriów oceny. Ich źródłem ma być język i kultura ${ }^{27}$. Lata 60. i 70. XX w. to także czas znaczącego rozszerzenia zakresu przedmiotowego pojęcia hermeneutyki, co przełożyło się na jego wieloznaczność 28 .

Hermeneutyka jako postawa poznawcza zrodziła się z konieczności interpretacji, o której decyduje istotowa polisemia języka ${ }^{29}$. Pojawienie się tego nurtu jawi się jako wynik różnicowania się światopoglądów i rozpad wspólnego horyzontu interpretacyjnego, który dokonał się w epoce nowożytnej ${ }^{30}$. Hermeneutyka jest więc korelatem tych samych zjawisk cywilizacyjnych co ideologia. Ma umożliwiać analizę tradycji jako fenomenu kulturowego, a zarazem zachowanie historyczno-kulturowej obiektywności sfery aksjologicznej. Hermeneutyka Gadamera (i częściowo Paula Ricoeura) nie tyle ujawnia nieodmienną kondycję ludzką, ile chce ją

27 Lista współczesnych autorów odwołujących się do idei hermeneutyki lub uważanych za hermeneutów zob. B. Baszczak, Paula Ricoeura hermeneutyka tekstu, s. 3, http://www.filozofia.pl/old/ zf06/prezentacje/bbaszczak.pdf (dostęp: 10 listopada 2014).

28 Np. A. Bronk, op. cit., s. 29-34; Hermeneutyka politologiczna. Na marginesie lektury Stevena Lukesa „Niezwykłe oświecenie profesora Caritata”, red. M. Kołodziejczak, Poznań 2009, s. 12; J. Sochoń, Hermeneutyka - wstępne rozpoznania, „Warszawskie Studia Teologiczne” 8, 1995, s. 219-220; B. Baszczak, op. cit., s. 3. Użyteczne jest też dokonane przez Richarda E. Palmera wyszczególnienie ze względu na wyróżniony moment interpretacji: biblijny, filologiczny, scjentystyczny, humanistyczny, egzystencjalny i kulturowy, sześciu współczesnych definicji hermeneutyki: 1) jako teorii egzegezy biblijnej; 2) jako ogólnej metodologii filologii; 3) jako nauki o wszelkim rozumieniu językowym (Schleiermacher); 4) jako metodologii nauk humanistycznych (Dilthey); 5) jako fenomenologii istnienia i rozumienia (Heidegger i Gadamer); 6) jako systemu interpretacji mitów i symboli (Ricoeur) - idem, Hermeneutics, Interpretation Theory in Schleiermacher, Dilthey, Heidegger and Gadamer, Evanston 1969, cyt. za: A. Bronk, op. cit., s. 27. Definicje te nie uwzględniają jednak wszystkich sposobów rozumienia tego pojęcia, pomijają np. hermeneutykę prawniczą. Zob. ibidem.

29 „Interpretacja polega [...] na rozpoznawaniu, jaki stosunkowo jednoznaczny sens został skonstruowany na polisemicznej podstawie wspólnego zasobu słów" - P. Ricoeur, op. cit., s. 193.

30 E. Kobylińska, Hermeneutyczna wizja kultury, Warszawa-Poznań 1985, s. 5-6. O rozróżnieniu na hermeneutykę filozoficzną i filozofię hermeneutyczną (filozofię przyjmującą założenia hermeneutyczne), wyróżnieniu typów hermeneutyki, lecz także dziejach hermeneutyki zob. A. Bronk, op. cit., s. 29-34; Hermeneutyka politologiczna..., s. 12, J. Sochoń, op. cit., s. 219-220, G. Scholtz, op. cit., s. 42; B. Baszczak, op. cit., s. 3 (jak już wspomniano, autor formułuje listę współczesnych autorów, odwołujących się do idei hermeneutyki lub uważanych za hermeneutów). 
zrozumieć drogą okrężną — poprzez kulturę. Ma być więc receptą na utratę sensu, sposobem na ponowny kontakt ze sferą symboliczną ${ }^{31}$.

Hermeneutyka w rozumieniu Gadamera i Ricoeura ma polegać na poruszaniu się po „kole hermeneutycznym” - od ogółu do szczegółu, po czym od szczegółu do ogółu - od wstępnego rozumienia analizowanego tekstu do uchwycenia jego specyfiki, a następnie do uzgodnienia sensu dzieła z założeniami, które legły $\mathrm{u}$ podstaw jego wstępnego rozumienia, a także do ich ewentualnej rewizji ${ }^{32}$. Należy więc „przejrzeć” swe uprzedzenia, nim przystąpi się do analizy ${ }^{33}$, świadomie rozpoznawać głos tradycji przemawiającej poprzez „,rzeczy same” ${ }^{34}$. Hermeneutyka polega na wrażliwości na inność tekstu, ale zarazem „taka wrażliwość jednakże nie zakłada ani treściowej »neutralności «, ani tym bardziej samolikwidacji, lecz zawiera świadome przyswojenie sobie własnych wstępnych mniemań i uprzedzeñ"35.

Istota metody hermeneutycznej na gruncie metodologii nauk historycznych Gadamera polega na postawieniu pytania tekstowi, co jest możliwe dzięki „zagadnięciu" przez tradycję. Tradycja jest przez tego filozofa rozumiana jako jedna z postaci autorytetu. Gadamer krytykuje oświeceniowe, aprioryczne odrzucenie tej idei. Wskazuje, że skoro każde poznanie jest uwarunkowane kulturowo, każde dokonuje się pod wpływem autorytetu — choćby fałszywego, głoszącego hasło odrzucenia wszelkiego autorytetu. Autorytet nie jest więc przeszkodą w rozumieniu ani nawet jego ograniczeniem, a jego warunkiem. Jego uznanie nie wynika $\mathrm{z}$ chęci uniknięcia odpowiedzialności za wyniki poznania ani z założenia o nieomylności jakiegoś źródła wiedzy. Jest natomiast rezultatem uświadomienia sobie konstytutywnych cech procesu poznawczego. Autorytet jest zjawiskiem z dziedziny poznania, a nie władzy. Gadamer wyróżnia autorytet osobowy — ma się go ze względu na cechy osobiste lub miejsce $\mathrm{w}$ hierarchii organizacji, którą ocenia się pozytywnie, oraz autorytet rzeczowy. Warunkiem posiadania prawdziwego autorytetu osobowego jest autorytet rzeczowy ${ }^{36}$, którego podstawowe źródło stanowi tradycja ${ }^{37}$. Gadamer potępia jej aprioryczne odrzucenie przez oświecenie, a zarazem odcina się od uprzedmiotawiającego, jego zdaniem, pojęcia tradycji, które legło u źródeł

31 E. Kobylińska, op. cit., s. 6-7, 12.

32 Abstrahuję tu od różnic między oboma autorami. Ricoeur kładzie nacisk na samoistny sens dzieła, którego „przyswojenie” ma polegać na przekształceniu zarówno (projektowanej) tożsamości jego autora, jak i postawy poznawczej jego odbiorcy poprzez kategorie właściwe dla „świata” zakładanego przez sens dzieła. Gadamer z kolei podkreśla znaczenie czasowości pojętej jednak nie tylko jako sposób istnienia podmiotu (Heidegger) lub psychologiczny warunek uznania samoistnego sensu dzieła (Ricoeur), lecz sposób konceptualizacji warunków wstępnych interpretacji - przesądów generowanych przez kulturową teraźniejszość i przeszłość. Zob. H.G. Gadamer, op. cit., s. 257.

33 Ibidem, s. 259-260.

34 Ibidem, s. 259.

35 Ibidem.

36 Ibidem, s. 267-268.

37 Ibidem, s. 268-272. 
jej pozornej afirmacji przez romantyzm i niemiecką szkołę historyczną ${ }^{38}$. Obie postawy wobec tradycji wynikają z założenia, że składa się ona z ustalonego zespołu sądów, które można w całości odrzucić lub w całości zaakceptować. Tymczasem według Gadamera tradycja to proces konstytutywny dla poznania, praktyka polegająca na wyrażaniu aktualnych problemów w języku sformułowanych już pytań, a następnie odpowiadaniu na nie przy uwzględnieniu wcześniej udzielonych odpowiedzi. Poznanie tradycjonalistyczne ma u interesującego nas w tym miejscu filozofa charakter dialogu, a nie kontemplacji czy iluminacji ${ }^{39}$. Istotne znaczenie ma więc skonceptualizowanie (cząstkowe) własnych „przesądów” co do danej materii.

Przesąd jest kolejną ideą, której wartość poznawcza została zapoznana zarówno przez oświecenie, jak i bezkrytyczny tradycjonalizm. Nie oznacza on jednak sądu błędnego, przyjmowanego bezrefleksyjnie, lecz wiedzę stanowiącą warunek poznania. W ten sposób następuje uświadomienie sobie poruszania się kręgu hermeneutycznym. Aby tekst mógł przemówić, należy go interpretować przy założeniu jego „doskonałości”. Jak wskazuje Gadamer, ma to niewiele wspólnego z wczuciem się w umysłowość autora, które proponowali Friedrich Schleiermacher i Wilhelm Dilthey. Polega natomiast na potraktowaniu tekstu jako partnera w interpretacji tradycji - wsłuchanie się w niego poprzez przypisanie mu spójności i racjonalności (prawdziwości) - założenia „jedności sensu”, a zarazem „oczekiwania sensu" 40 . W końcu następuje ponowna interpretacja tekstu i przesądów - stwierdzenie, że tekst je potwierdza i jest z nimi zgodny lub że ujawnia niezgodność z nimi, a więc iż wymagają one modyfikacji, odrzucenia albo właśnie potwierdzenia.

Jeśli uprzedzenie staje pod znakiem zapytania - w obliczu tego, co nam mówi ktoś inny lub jakiś inny tekst - to nie oznacza to, że zostaje ono odsunięte po prostu na bok, a jego miejsce zajmuje od razu inny lub coś innego [...]. W rzeczywistości zaś własne uprzedzenie zostaje wprowadzone do gry przez to, że samo jest stawką w grze $^{41}$.

Otwartość na tekst nie jest jednoznaczne z przyjęciem perspektywy autora tekstu - oznaczałoby to uprzedmiotowienie tekstu i wyłączenie z procesu tradycji ${ }^{42}$.

Do przeprowadzenia wszystkich tych etapów procesu poznawczego konieczne jest zastosowanie tekstu do konkretnego problemu stojącego przed interpretatorem. Tutaj wzorem dla hermeneutyki filologicznej jest hermeneutyka biblijna

38 Tymczasem wszelka tradycja czy mityczny ogląd świata ma już w jakimś stopniu charakter poznania (dopuszcza, że coś może lub mogłoby być inaczej). „Wszelka świadomość mityczna jest już zawsze wiedzą i jeśli zna boskie moce, to wykracza ponad zwykłe drżenie z lęku przed mocą (jeśli uznawać je za stadium pierwotne), ale i ponad zaklęte w magicznym rytmie życie zbiorowe (jak np. we wczesnych epokach Wschodu). Wie ona o sobie, a w tej wiedzy nie jest wprost poza sobą" - ibidem, s. 263.

39 A. Bronk, op. cit., s. 239.

40 H.G. Gadamer, op. cit., s. 280.

41 Ibidem, s. 284.

42 Jak to określił Bronk, „[m]uszę tego drugiego człowieka zrozumieć właśnie jako drugiego. Gdybym się z nim zidentyfikował, przekreśliłbym go jako drugiego i tym samym nie byłoby to już moje rozumienie" - idem, op. cit., s. 258. 
i prawnicza, w których akt zastosowania nie jest oddzielony od aktu poznania ${ }^{43}$. Zdaniem Gadamera należy odwołać się również do Arystotelesowskiej kategorii fronensis ('samo-wiedzy' - cnoty roztropnego namysłu) oraz prawa naturalnego, pojętego jako wiedza, która ma charakter rozumny, ale ujawnia się w konkretnych przypadkach poprzez „przewodnie obrazy”, a nie normy. Analiza Arystotelesowska jest „modelem problemów hermeneutyki” jako metody, na gruncie której interpretator stosuje tradycję do samego siebie. W koncepcji Arystotelesa „przeciwieństwem widzenia tego, co słuszne, nie jest błąd lub złudzenie, lecz zaślepienie” - poddanie się namiętnościom ${ }^{44}$. Stąd egzemplaryczne znaczenie hermeneutyki prawniczej. Pozycja prawnika interpretującego prawo współczesne i historyka prawa jest z punktu widzenia hermeneutyki taka sama - obaj odnoszą tekst do konkretnego współczesnego problemu, rozpatrując go w horyzoncie tradycji. Ma ona zarazem charakter subiektywny i obiektywny - hermeneutykę prawniczą umożliwia powszechne obowiązywanie prawa - tam, gdzie prawo może być wykładane dowolnie, gdzie prawem jest słowo władcy, tam nie ma hermeneutyki ${ }^{45}$.

Pojawia się pytanie, czy taka metodologia nie implikuje, z jednej strony, bezkrytycznego uznania tradycji i analizowania tekstu według jej kryteriów, z drugiej zaś, czy - poprzez przypisanie mu „doskonałości” - nie prowadzi do relatywizmu. Pierwszy zarzut stawiają Gadamerowi Jürgen Habermas i John Caputo. Autor Teorii działania komunikacyjnego zarzuca filozofowi rezygnację z obiektywizmu poznania i popadnięcie w irracjonalizm ${ }^{46}$; drugi, przyjmując, że Gadamer traktuje tradycję jako ustalony zespół sądów, twierdzi, iż w takim wypadku nawet interpretacja dzieła przynoszącego nowe treści nie może zmienić jej rozumienia. Tymczasem Georgia Warnke zarzuca Gadamerowi, że założenie doskonałości tekstu uniemożliwia jego krytykę - jeśli przyjąć, że każdy tekst objawia prawdę, jest spójny, to jako objawiające sens tradycji należy interpretować nawet teksty w rodzaju Mein

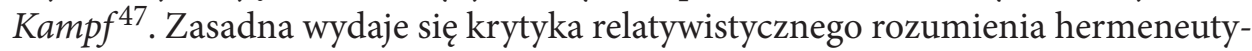
ki zaprezentowana przez C.E. Atkinsona. Rozumie on hermeneutykę Gadamera jako koncepcję zakładającą historyczność i kontekstualność interpretacji, jednak bez uwarunkowania przez tradycję o określonej treści. Gadamer, traktując tradycję jako proces, nie wykazuje przywiązania do tradycji pojętej jako określony zespół przekonań ${ }^{48}$. Uświadomienie sobie uwarunkowania przez tradycję nie wyklucza zatem zajęcia wobec niej pozycji krytycznej. W tej perspektywie odwołanie

43 H.G. Gadamer, op. cit., s. 291-294.

44 Ibidem, s. 294-305.

45 Ibidem, s. 305-310.

46 Z. Krasnodębski, Rozumienie i emancypacja. Spór między teorią krytyczną i hermeneutyczną, „Archiwum Historii Filozofii i Myśli Społecznej” 1979, nr 25, s. 301-328.

47 C.E. Atkinson, Is Gadamer's hermeneutics inherently conservative?, „Forum Philosophicum: International Journal for Philosophy" 2, 2009, nr 14, s. 289-299.

48 Ibidem, s. 289 n. Podobne rozumienie tradycji prezentują niektórzy myśliciele konserwatywni, np. Edmund Burke czy Maurycy Barrès. Zob. A. Barut, Egotyzm, etyka, polityka. Myśl konserwatywna Maurycego Barrèsa, Kraków 2009, s. 30-31. 
do tradycji to uznanie radykalnej czasowości istnienia i rozumienia. Uznanie to decyduje o tym, że Gadamer nie postrzega tradycji, wbrew twierdzeniom Caputo, jako nośnika prawd ponadczasowych ${ }^{49}$. Odnosząc się do krytyki sformułowanej przez Warnke, Atkinson stwierdza, że dla Gadamera kryterium spójności i adekwatności tekstu nie jest zamiar autora. Nie chodzi o to, aby każdy tekst mógł prowadzić do zakwestionowania przesądów interpretatora, lecz aby doświadczenie interpretacji tekstu mogło prowadzić do spojrzenia na przesądy w innym świetle ${ }^{50}$. Nie należy więc z góry dyskwalifikować żadnego tekstu, lecz właśnie analizując go świetle przesądów, poddawać je próbie, a zarazem dzięki nim oceniać go. Tylko bowiem poddając swoje przesądy próbie kontaktu z tekstem, umożliwiającej ich potwierdzenie lub odrzucenie, można twierdzić, iż tekst się zrozumiało ${ }^{51}$.

Ostatecznie według Atkinsona Gadamerowskie idee tradycji czy doskonałości to idee regulatywne $e^{52}$. Podobnie otwartą interpretację koncepcji Gadamera przedstawiła Ewa Kobylińska. Gadamer, jak twierdzi badaczka, proponuje nowy model kultury, praktyki symboliczno-komunikacyjej odróżnianej od religii i świeckich światopoglądów metafizycznych. Założenia jej semantyki mogą być jednak poddane namysłowi, wzięte w „nawias epistemologiczny” ${ }^{33}$. Również Grażyna Woro-

49 C.E. Atkinson, op. cit., s. 295-297. Nie przeczy temu również odwoływanie się Gadamera do „klasycyzmu” - jeśli nawet jakieś dzieła uznawane są za klasyczne, to tylko dlatego, że wciąż do nas przemawiają — ich klasyczność jest potwierdzana dzięki naszemu ich rozumieniu, temu, że są ważne dla nas i uznaniu przez nas za klasyczne (ibidem, s. 291). Jak wskazuje np. przeprowadzona przez Gadamera analiza Arystotelesowskiej fronensis - mająca stanowić przykład zastosowania hermeneutyki - nie chodzi o to, że wciąż uznaje się bohaterów antycznych za wzory męstwa, lecz o to, że do współczesnych przemawia idea cnoty jako punktu pośredniego między skrajnościami. Sam ideał klasyczny nie ma pozytywnej treści, wymaga bowiem „zastosowania”, postawienia aktualnego pytania, ponieważ rozumieć można tylko to, co się odnosi do sytuacji i problemów interpretatora. Zdaniem Atkinsona fuzja horyzontów nie oznacza u Gadamera połączenia tradycji w sensie zespołu sądów, lecz stawianie wspólnych pytań (ibidem, s. 292-297). Jeśli tak rozumieć tę ideę Gadamera, to niezasadny staje się zarzut Andrzeja Szahaja, który akceptuje hermeneutykę Gadamera, stwierdzając jednak, że metafora fuzji horyzontów jest nietrafna, gdyż opiera się na założeniu, że istnieją obiektywne horyzonty interpretatora i autora, które mogą się „stopić”, tymczasem jedyna obiektywność to obiektywność sensu, jaki nadaje tekstowi wspólnota interpretacyjna (idem, Siła i słabość hermeneutyki, „Teksty Drugie” 2012, nr 12, s. 87-94).

50 C.E. Atkinson, op. cit., s. 297-299.

51 Ibidem, s. 304.

52 Ibidem, s. 299-302. U Gadamera ma występować prymat pytania nad odpowiedzią. Wskazywanym przez filozofa przykładem takiego powracającego pytania, na które wciąż udziela się nowych odpowiedzi, jest odziedziczone po Grekach pytanie o Logos. Ostatecznie, zdaniem Atkinsona, Gadamer nie jest ani konserwatystą, ani relatywistą, jego celem jest wskazanie na skończoność i historyczność podmiotu (ibidem, s. 305-306).

53 Gadamer, zdaniem Kobylińskiej, odróżnia sferę przedrozumienia - niepoddającą się w zasadzie konceptualizacji (w czym widoczna ma być inspiracja Heideggera) - oraz sferę przesądów kulturowych, poddających się refleksji (co stanowić ma inspirację Kantowską) (zob. E. Kobylińska, op. cit., s. 11-12, 118). Jednostka, czerpiąc wzory zachowań ze sfery kultury - sfery obiektywnej - winna jednak dokonywać autonomicznych wyborów (ibidem, s. 14-16). Zdaniem badaczki w świetle teorii Gadamera można wyróżnić trzy poziomy partycypacji kulturowej: poziom przedpo- 
niecka przyjmuje interpretację idei Gadamera opartą na założeniu względnej swobody jednostki w procesie interpretacji, a przez to zmiany wartości i norm kulturowych ${ }^{54}$.

Oceniając dynamiczne sposoby rozumienia Gadamerowskich idei tradycji, należy się zgodzić, iż niewątpliwie hermeneutyka tego filozofa może pełnić funkcję krytyczną wobec przesądów przyjmowanych bezrefleksyjnie (w szczególności przesądu scjentystycznego ${ }^{55}$ ). Trzeba jednak zauważyć, że tak rozumiana hermeneutyka nie może rezygnować z koncepcji tradycji przynoszącej pewne ustalone wartości i sądy, choćby były one nie do końca sprecyzowane. Podejście hermeneutyczne traci swoją specyfikę, jeśli tradycja zaczyna przybierać jedynie postać zbioru symboli, mówiąc językiem teorii Laclau „pustych znaczących”, pod które można podstawić dowolne desygnaty. Tradycja nie może oznaczać jedynie woli interpretacji. Nie można też takiego stanowiska przypisywać Gadamerowi, który podkreślał znaczenie autorytetu, którego najważniejszym źródłem być właśnie tradycja ${ }^{56}$.

\section{Autorytet w hermeneutycznie zorientowanej filozofii polityki}

Pojęcie autorytetu prowadzi do filozofii polityki, w szczególności w jej wersji hermeneutycznej prezentowanej przez Hannah Arendt, a także Carla Schmitta. $\mathrm{Na}$ jej gruncie spotykamy bowiem ideę autorytetu zbliżoną do Gadamerowskiej. Autorytet Arendt, podobnie jak autorytet Gadamera, nie przekazuje określonej treści, lecz uprawomocnia pewną tradycję kulturową; w ten sposób uzasadnia pewien porządek polityczno-prawny, nie sprowadzając go do określonej ideologii czy rozwiązania instytucjonalnego. Jest to wyrazem konieczności wsłuchania się we wspólny ethos polityczny, pojmowany choćby jako horyzont rozumienia. Sprzeczny z nim jest zarówno kulturowo-etyczny relatywizm, jak i ideologiczna afirmacja

jęciowego przeżycia - prywatny fundament aksjologiczny, poziom żywej mowy — odpowiadający indywidualnemu użytkowaniu semantyki przez uczestników wspólnoty komunikacyjnej, wreszcie poziom uprzedmiotawiającej świadomości naukowej — estetycznej, językowej i historycznej — poziom ukształtowania społecznego semantyki komunikacji symboliczno-kulturowej. Stosunek poziomu II do III jest zawsze krytyczny (ibidem, s. 117).

54 Wroniecka odwołuje się do przedstawionej przez Kobylińską koncepcji trzech poziomów partycypacji kulturowej, uznając, że przesądy należą do pierwszego poziomu i to zasadniczo one jako warunek rozumienia i swobodnego wyboru, cząstkowo tylko możliwy do konceptualizacji, muszą pozostać niezmienne (eadem, Interakcja symboliczna a hermeneutyczna kategoria przed-rozumienia, Warszawa 1998, s. 54-57). Autorka przyznaje zresztą, że formułując swą ideę interakcji symbolicznej, modyfikuje stanowisko Gadamera (ibidem, s. 58).

55 A. Bronk, op. cit., s. 71-72.

56 Atkinson, chociaż w swej polemice mocno akcentuje „otwarty” charakter tradycjonalizmu Gadamera, wskazuje zarazem, że u tego filozofa pytania ograniczają liczbę możliwych odpowiedzi. „[C]zym są przesądy, jak nie szczególnymi ograniczeniami (particular limitations), które nie pozwalają nam osiągnąć ani stanu absolutnej świadomości ani pełnej otwartości” - idem, op. cit., s. 304. 
określonego stanu rzeczy. Właśnie uznanie autorytetu, chociaż nie daje gotowych odpowiedzi, pozwala widzieć rzeczywistość polityczną w jej specyfice.

Według Arendt autorytet to perswazja, która ma moc niemożliwą do pominięcia dzięki pozycji piastuna autorytetu. Właściwie pojęcie to prezentowali już Rzymianie $^{57}$. Autorytet Rzymian był zakotwiczony w zdarzeniu politycznym akcie założenia miasta, które jednak, jako zdarzenie illo tempore, przekraczało polityczną empirię. Miał więc charakter religijny w sensie funkcjonalnym: piastunem autorytetu był senat, nie będąc zarazem jego samoistnym źródłem ${ }^{58}$. Autorytet uprawomocniał rzymską tradycję: odwołanie do tego aktu stabilizowało życie polityczne Rzymian, nadając mu gravitas ${ }^{59}$. Wraz z nowożytnością nadszedł jego kryzys, nierozłącznie związany z kryzysem politycznym religii i tradycji. Zachwianie pozycji autorytetu jest jednak przede wszystkim kryzysem polityczności społeczeństwa, wyraża odrzucenie samoistności i specyfiki działania politycznego, niesprowadzalnego do techniki ${ }^{60}$.

Właśnie autorytet umożliwia podmiotową różnorodność, wyrażającą się w sferze publicznej. Skutki zaniku autorytetu ujawniła rewolucja francuska. Rewolucja ta odeszła bowiem od jedynie właściwego, zdaniem Arendt, rozumienia wolności, tj. utożsamienia jej z równą możliwością działania politycznego. Zidentyfikowała ją natomiast z równością „naturalną” - przypisaną ludziom cechą mającą być niezależną od ich przejawiania się na płaszczyźnie politycznej. W ten sposób, nawet jeśli „burżuazyjna” rewolucja francuska nie posługiwała się, w szerokim zakresie, hasłami równości ekonomicznej i społecznej, to jednak otworzyła drogę do ich formułowania. Wprowadziła w ten sposób do polityki masy podległe konieczności biologicznej wynikającej z nędzy. Wejście do polityki kwestii socjalnej wyzwala litość i współczucie - uczucia apolityczne. Nie można stawiać ograniczeń w realizacji wyznaczonych w ten sposób celów. Jako niepolityczne mogą być one osiągnięte drogą przemocy, dlatego uzasadniają absolutyzm ideologiczny i fanatyzm praktyczny ${ }^{61}$. Rewolucja francuska gorączkowo poszukiwała więc autorytetu, który mógłby ją uprawomocnić, stąd groteskowe zdaniem Arendt pomysły, jak kult Najwyższej Istoty wprowadzony przez Maximiliena de Robespierre’a. Poszukując autorytetu, poszukiwała absolutu, który miał spełniać funkcję taką jak niegdyś Bóg, czyli być zjawiskiem pozapolitycznym ${ }^{62}$.

57 H. Arendt, Między czasem minionym a przyszłym. Osiem ćwiczeń z myśli politycznej, przeł. M. Godyń, W. Madej, Warszawa 1994, s. 114-115. Arendt pisze (za Theodorem Mommsensem) o rzymskim autorytecie: ,jest czymś więcej niż poradą i mniej niż rozkazem, jest to porada, której nie można zignorować bez obaw" - ibidem, s. 151 .

58 Stąd zasada, że władza pochodzi od ludu, autorytet — od senatu. Chrześcijaństwo przejęło ideę autorytetu, instytucjonalizując Kościól, autorytet ten odwoływał się do wcielenia Boga - aktu historycznego (ibidem, s. 157-167).

59 Ibidem, s. 148-157.

60 Ibidem, s. 171-172.

61 H. Arendt, O rewolucji, przeł. M. Godyń, Warszawa 2003, s. 69 n.

62 Ibidem, s. 229-232. 
Arendt podkreśla różnicę między amerykańską (1776) i francuską deklaracją praw (1789). Ta pierwsza miała chronić przed nadużyciami władzy prawa jednostki już wyposażonej w status polityczny. Druga ustanawiała prawa człowieka i obywatela jako fundament społeczeństwa politycznego, traktując jednostkę jako istotę naturalną, nie-polityczną ${ }^{63}$. Różny był więc sposób rozumienia źródła władzy politycznej. Rewolucja amerykańska wywodzi władzę centralną z mnogości władz lokalnych: komitetów, władz hrabstw, władz stanowych. Była to zdaniem Arendt realna podstawa legitymizacji, zapewniająca stabilność. Z kolei rewolucja francuska wyprowadzała legitymizację władzy z woli narodu: fikcji, której nie dało się na gruncie ideologii rewolucyjnej skonkretyzować pod groźbą utożsamienia „woli powszechnej” z wolą empirycznie istniejącej grupy ludzi - „woli wszystkich”. Charakteryzujące rewolucję francuską utożsamienie źródeł władzy i prawa było skutkiem braku ponadpolitycznego autorytetu, którego rolę w USA pełni Konstytucja - akt z nieodległej stosunkowo historii, jednocześnie przekraczający polityczną empirię ${ }^{64}$. Źródłem prawa nie jest już przemyślane uzgodnienie, świadomy wybór, dokonany w drodze wspólnego rozumowania i wzajemnego przekonywania, lecz wola. Co więcej, nie jest to wola większej liczby obywateli, lecz „wola powszechna”. Wola w znaczeniu uzgodnienia zakładała uprzednie istnienia społeczności politycznej, podczas gdy wola powszechna dopiero ją tworzy ${ }^{65}$. Francuskie dążenie do wolności publicznej, identyfikowanej z wyzwoleniem ludu $\mathrm{z}$ nędzy, $\mathrm{z}$ ciągłym stanem nowego początku przejawiło się $\mathrm{w}$ stanie rewolucji permanentnej - jedynym stanie, w którym wolność publiczna zostaje zachowana ${ }^{66}$.

Polityczny charakter autorytetu jako czerpiącego swą siłę z nietożsamości z instytucjąa, ideą czy osobą podkreślał również Schmitt. Dla tego filozofa źródłem wszystkich idei politycznych (również tych składających się na ideologie antyreligijne) są pojęcia teologiczne (idea stanu wyjątkowego odpowiada idei cudu, z kolei liberalizm i idea rządów prawa pozytywnego odpowiadają deizmowi ${ }^{67}$. Kościół katolicki jest przykładem - rzadkim w świecie współczesnym Schmittowi - myślenia politycznego. Swój autorytet czerpie on bowiem z reprezentowania rzeczywistości nadziemskiej - Chrystusa. Idea, którą chce wyrażać Kościół, nie rości sobie jednak pretensji do pełnego i całościowego opisu świata, dlatego też unika

63 Ibidem, s. 133-134.

64 Ibidem, s. 200-211.

65 Ibidem, s. 91. Nie jest ona związana z partykularnym interesem, który może być wyrażony na scenie publicznej. Aby kierować się wolą powszechną, trzeba zwalczyć w sobie wolę partykularną, tę właśnie, która zakotwiczyła politycznie rewolucję amerykańską (ibidem, s. 91-94). Paradoksalnie, niepolityczny charakter rewolucji francuskiej przejawia się w tym, że w przeciwieństwie do rewolucji amerykańskiej nie przyjęła ona za swe hasło dążenia do szczęścia, lecz do wolności. Tymczasem, zdaniem Arendt, to właśnie dążenie do szczęścia we wspólnocie politycznej - rywalizacja, porównywanie się, oddziaływanie - składa się na istotę polityczności (ibidem, s. 147-148).

66 Ibidem, s. 164-167.

67 C. Schmitt, Teologia polityczna i inne pisma, przeł. M.A. Cichocki, Kraków-Warszawa 2000, s. $60-61$. 
charakterystycznego dla nowożytności dualizmu ideologicznego (implikującego bezwzględne zwalczanie przeciwnika) lub automatycznej, zadekretowanej syntezy. Idea ta nie istnieje więc wyłącznie w światowości, co nie przeszkadza temu, że chce się w niej wyrazić $\mathrm{i}$ ją kształtować - zachowuje zatem nierozerwalny związek $\mathrm{z}$ władzą. W związku z tym Kościół jest instytucją par excellance polityczną. Stanowi przykład przednowożytnego, lecz także ponadczasowego, ponieważ prawdziwie ludzkiego, doświadczenia i widzenia świata ${ }^{68}$. Kościół posługuje się tym wszystkim, co ustanawia wspólną symbolikę, umożliwia wspólne bytowanie: retoryką (czerpanie ze wspólnych tematów i toposów), formą estetyczną (znaczenie obrzędowości), formą prawną (Kościól jak sędzia rozstrzyga o sprawach przekraczających bieżącą grę interesów), wreszcie formą polityczną. Dlatego Kościół w perspektywie nowożytnej jawi się jako „mieszanina przeciwieństw”, ewentualnie instytucja zabiegająca wyłącznie o władzę i przetrwanie, potrafiąca łączyć się z każdą ideologią. Jest tak z tego względu, że stanowi przeciwieństwo dominującego w nowożytności myślenia ekonomicznego, technicznego i prywatno-etycznego, urzeczowiających stosunki społeczne ${ }^{69}$.

$* * *$

Postmodernizm, zakładając dekonstrukcję wszelkich tożsamości, nie może jednak założyć dekonstrukcji samego procesu krytycznego - samej dekonstrukcji. Szczególnie dogodną metodą dekonstrukcji zastanych kategorii kulturowych okazują się mechanizmy polityczno-prawne, co przekłada się - przynajmniej na horyzoncie myśli postmodernistycznej - na ich afirmację jako warunków, a w dalszej kolejności metod krytyki. Hermeneutyka z kolei, chociaż odwołuje się do pojęć z punktu widzenia postmodernizmu „metafizycznych”: m.in. autorytetu, tradycji, fuzji horyzontów, to jednak, dzięki świadomemu odrzuceniu możliwości ich utożsamienia z określonymi teoriami i ideologiami, może służyć zarówno jako podstawa krytyki instytucji, jak i punkt wyjścia do odbudowy ładu politycznego.

\section{Bibliografia}

Arendt H., Między czasem minionym a przyszłym. Osiem ćwiczeń z myśli politycznej, przeł. M. Godyń, W. Madej, Warszawa 1994.

Arendt H., O rewolucji, przeł. M. Godyń, Warszawa 2003.

Atkinson C.E., Is Gadamer's hermeneutics inherently conservative?, „Forum Philosophicum: International Journal for Philosophy" 2, 2009, nr 14.

Banasiak B., Filozofia „końca filozofi”. Dekonstrukcja Jacquesa Derridy, Warszawa 1997.

Banasiak B., Jacques Derrida - najgłośniejszy myśliciel XX wieku, http://bb.ph-f.org/teksty/bb_derrida. pdf.

\footnotetext{
68 Ibidem, s. 84-114.

69 Ibidem, s. 90-99.
} 
Barut A., Egotyzm, etyka, polityka. Myśl konserwatywna Maurycego Barrèsa, Kraków 2009.

Baszczak B., Paula Ricoeura hermeneutyka tekstu, http://www.filozofia.pl/old/zf06/prezentacje/bbaszczak.pdf.

Bronk A., Rozumienie, dzieje, język. Filozoficzna hermeneutyka H.-G. Gadamera, Lublin 1988.

Critchley S., The Ethics of Deconstruction. Derrida and Levinas, Oxford-Cambridge 1992.

Derrida J., Force of law, [w:] G. Anidjar, J. Derrida, Acts of Religion, London-New York 2002.

Derrida J., Różnia, [w:] Drogi współczesnej filozofii, red. M.J. Siemek, przeł. S. Cichowicz et al., Warszawa 1978.

Foucault M., Historia seksualności, przeł. B. Banasiak, T. Komendant, K. Matuszewski, t. 3, Warszawa 1995.

Foucault M., Nadzorować i karać, przeł. T. Komendant, Warszawa 1993.

Gadamer H.G., Prawda i metoda. Zarys hermeneutyki filozoficznej, przeł. B. Baran, Kraków 1993.

Habermas J., Filozoficzny dyskurs nowoczesności, przeł. M. Łukasiewicz, Kraków 2007.

Herer M., Gilles Deleuze. Struktury - maszyny - kreacje, Kraków 2006.

Hermeneutyka politologiczna. Na marginesie lektury Stevena Lukesa „Niezwykłe oświecenie profesora Caritata", red. M. Kołodziejczak, Poznań 2009.

Kobylińska E., Hermeneutyczna wizja kultury, Warszawa-Poznań 1985.

Krasnodębski Z., Rozumienie i emancypacja. Spór między teorią krytyczną i hermeneutyczną, „Archiwum Historii Filozofii i Myśli Społecznej" 1979, nr 25.

Laclau E., Emancypacje, przeł. L. Koczanowicz et al., Wrocław 2004.

Laclau E., Populism: what's in a name?, www.essexs.ac.uk/centres/theostud/documents_and_files/ Word/Populism\%20Whats\%20in\%20a\%20name.doc.

Lambert G., Critical horizons, „Brill Academic Publishers” 4, 2003, z. 2.

Lefebvre A., The Image of Law: Spinoza, Bergson, Deleuze, Stanford 2008.

Markowska B., Gramatologia jako projekt polityczny: dekonstrukcja i kwestia sprawiedliwości, „Idea” 2008 , nr 20, s. 8.

Markowski M., Tożsamość i dekonstrukcja, http://p-ntzp.com/dok/11Markowski-p.pdf.

Raffoul F., Derrida and the ethics of Im-possible, „Research in Phenomenology” 38, 2008.

Ricoeur P., Język, tekst, interpretacja: wybór pism, przeł. P. Graff, K. Rosner, Warszawa 1989.

Schmitt C., Teologia polityczna i inne pisma, przeł. M.A. Cichocki, Kraków-Warszawa 2000.

Scholtz G., Czym jest i od kiedy istnieje "filozofia hermeneutyczna”, [w:] Studia z filozofii niemieckiej, red. S. Czerniak, J. Rolewski, t. 1. Hermeneutyczna tożsamość filozofii, Toruń 1994.

Smart B., Postmodernizm, przeł. M. Wasilewski, Poznań 1998.

Sochoń J., Hermeneutyka - wstępne rozpoznania, „Warszawskie Studia Teologiczne” 8, 1995.

Szahaj A., Siła i słabość hermeneutyki, „Teksty Drugie” 2012, nr 12.

Wroniecka G., Interakcja symboliczna a hermeneutyczna kategoria przed-rozumienia, Warszawa 1998.

Žižek S., Wzniosły obiekt ideologii, przeł. J. Bator, P. Dybel, Wrocław 2001. 